\title{
The Implementation of School Based Management in Primary School
}

\author{
Eliza Haryanti \\ Madrasah Ibtidaiyah Riyadhul Jannah \\ Email: elizaharyanti8@gmail.com \\ Edi Harapan \\ Universitas PGRI Palembang, Indonesia \\ e-mail: ehara205@gmail.com \\ Nila Kesumawati \\ Universitas PGRI Palembang, Indonesia \\ e-mail: nilakesumawati@yahoo.com \\ Article History: Received on 14 November 2021, Revised on 17 January 2022 \\ Published on 23 January 2022
}

\begin{abstract}
This study aims to review and describe the school based management in Madrasah Ibtidaiyah Riyadhul Janah in Palembang. This is descriptive qualitative research. The subject was teachers in Madrasah Ibtidaiyah Riyadhul Janah Palembang. Data in this study was collected by interviews and analyzed using triangulation. The results stated that school based management will take place effectively and efficiently when supported by human resources professional to operate schools, sufficient funds, so schools are able to hire staff in accordance with its function, infrastructure to support the process, parents and community support significantly better in thought and favors a significant contribution.
\end{abstract}

Keywords: School Based Management, Quality, Education, Madrasah Ibtidaiyah

\section{A. Introduction}

School based management is one of its models bureaucracy reform provided decentralization in education sector to create a form of school a better future than to one previously. Encourage school based management stressed that the concept has referring to resources management at the school level and not in a system or degree of being centralized (Hasbullah, 2012).

One of the most important feature of the mbs is how the school able to provide a satisfactory education services to parents and the students, and vice versa where readiness and the role of the people and parents students in contributing to develop and increase the quality of schools in accordance with the needs of the people. The application of school-based management needs readiness in a variety of components and devices education both internally and externally that could support the implementation of the mbs itself among others: School buildings equipped with the facilities and infrastructures under learning, the school principal, teachers and education staff, school tuition, the vicinity of the school the role of students and parents, of the people and business support other (Supriadi, 2014). The main problems now is the quality of education are more reliant on the issue of the quality of graduates produced by a unit of education itself. Aziz (2012) explained that in general the quality of yourselves to a degree of excellence a product, services such as well whether real or not real. 
In the context of education, understanding is referring to quality educational process includes, input as, teaching materials, methodology of school infrastructure, administrative support, infrastructure other resources and the creation of a conducive atmosphere (Baharuddin, 2017; Nuryani et al, 2021). Hence, the quality of education yourselves the resources transform schools in various types of input and a certain degree of added value for learners, Included in the order the quality of the educational process it is healthier, security, discipline, familiarity, mutual respect, satisfaction and lain-lain of objects and received during the service.

Based on the background problem above, identified the existing problems, the school-based management is executed in curriculum, student affairs, infrastructures, quality of teachers, financing. In the implementation of the quality management had been considered out of schoolbased well even though it can be said has not yet been optimized, as management of the quality of teachers, where teaching still do not linear of a discipline of sciences, facilities management was incomplete such visual aids mathematics, science and social studies, financing management rely solely on the bos funds, because it is private schools (Efendi et al, 2020).

The school based management in terms of curriculum had proceeded in accordance with prevailing curriculum, but still need of improvement so that the better arising (Frinza et al, 2020). Management of infrastructures still need to be improved, because there are still some seats of students should be fixed, the table of students, flapon, the blackboard. In addition, the visual aids such as the picture attached a hero have already started to look in vain for relief (Febrilia, 2017; Hadziq, 2016).

In the process of administrative management in Madrasah Ibtidaiyah Riyadhul Janah Palembang was given by the school principal, making letters, all school data, school goods, list of students. But it is still considered not optimal, not accurately labeled numbering in accordance with a list of goods inventory.

School based quality management applied reference to the management curriculum, student affairs, teacher, the financial and financing, infrastructures, relationship and the community. In the process of learning assisted by 14 teachers teaching staffs, which consist of 2 civil servant teachers and 12 teachers paid by honorarium. In terms of teacher management, in carrying out learning activities not all teachers are linear with a discipline of sciences, sometimes teachers in carrying out learning does not provide the motivation to students. In terms of management of infrastructures it can be said has not yet been optimized, because is still less source of learning, the books in the library is weak, as diction and non diction, children story books. In terms of curriculum management, it can be said is strong, where teachers in planning, carry out of learning, evaluate, follow up and provide counseling is in accordance with a set curriculum (Sunanto, 2015).

\section{B. Methods}

The research is the qualitative study, with a view to acquire understanding of deep and its interpretation of the meaning of the phenomenon in the field. The subjects were teachers in Madrasah Ibtidaiyah Riyadhul Janah Palembang. Data were collected using interview, observation and documentation. The data were analyzed using triangulation (Sugiyono, 2015; Sudaryono, 2009; Moleong, 2011). 


\section{Results and Discussion}

In the school based curriculum management in improving the quality of education in Madrasah Ibtidaiyah Riyadhul Janah Palembang were outcomes of the curriculum developed and planned and renewed annually. Obstacles in the management of the curriculum is planning are still refer to a device the previous year. Achievement from learning refers to curriculum that can be improved and increased (Rohma et al, 2020).

In terms of the management of infrastructure, the school based management in improving the quality of education in Madrasah Ibtidaiyah Riyadhul Janah Palembang using the school operational fund, in addition to receive assistance in the form of the tools (Hariyanto et al, 2021). Obstacles in the submission of the proposal is the slow response from related parties so the schools look for alternative ways of involving the parents and the students and alumni involved the company, such as Pusri help to supply the infrastructure is in school. Through school based management that have drawn up the obstacles to be overcome by effect existing facilities before the replacement infrastructure that was deemed unsuitable (Syahru, 2017).

In terms of management enhance the quality of teachers, through school based management the attainment of which was carried out from the results of the application of school-based management in terms of quality of teachers, enhance the performance of educators, educators can carry out learning process well (Merdekawati, 2017). Through the application of school based management, it had been considered good teachers, because supported by fields of teaching staff who were carried out in accordance with duty. The teachers should motivate students. Obstacles in the application of school based management is in increasing the quality of teachers (Widyastuti, 2016).

In terms of student, curriculum the school based management statehs the result is that the management of school based activities. Saturday religious activities, where this activity focused on ability students. The obstacles in the management in school based curriculum it is still have violation done by students about good governance at school (Zaini, 2015).

\section{Conclusion}

Based on the research it can be concluded that school based management will take place effectively and efficiently when supported by human resources to operate schools, professionally for sufficient funds so schools are able to hire staff according to them, adequate infrastructure to support the teaching and learning process, and community support (parents) significantly better in thought and assistance a significant contribution.

\section{E. Acknowledgement}

We thank to Madrasah Ibtidaiyah Riyadhul Janah in Palembang, Rector Universitas PGRI Palembang, Director of Graduate Program and friends of graduate program educational management Universitas PGRI Palembang who have supported us to do this project.

\section{References}

Aziz. (2012). Penerapan Manajemen Berbasis Sekolah/Madrasah dalam Meningkatkan Mutu Pendidikan di MTs Alkhairaat Sandana Kabupaten Tolitoli [Implementation of 
School/Madrasah-Based Management in Improving the Quality of Education at MTs Alkhairaat Sandana, Tolitoli Regency]. Jurnal Manajemen dan Administrasi Pendidikan, 2(3), 177-192.

Baharuddin. (2017). Penguatan Manajemen Peningkatan Mutu Berbasis sekolah (MPMBS) [Strengthening School-Based Quality Improvement Management (MPMBS)]. Jurnal Idaarah, 1(1), 14-22.

Efendi, R., Fitria, H., \& Nurkhalis, N. (2020). Effect of Role School Committee and School Operational Fund on Quality of Education. Journal of Social Work and Science Education, 1(2), 194-203. https://doi.org/10.52690/jswse.v1i2.48

Febrilia. M. (2017). Implementasi Manajemen Berbasis Sekolah di SMP Negeri 3 Tanjung Raja Kabupaten Lampung Utara [Implementation of School-Based Management at SMP Negeri 3 Tanjung Raja, North Lampung Regency]. Jurnal Manajemen dan Administrasi Pendidikan, 2(1), 163-178.

Frinza, F., Kristiawan, M., \& Houtman, H. (2021). Curriculum Management in Early Childhood Education. Journal of Social Work and Science Education, 1(3), 289-297. https://doi.org/10.52690/jswse.v1i3.122

Hadziq, A. (2016). Implementasi Manajemen Berbasis Sekolah dalam Mewujudkan Sekolah Efektif di MTs NU Sabilul Muttaqin Jepang Mejobo Kudus [Implementation of SchoolBased Management in Realizing Effective Schools at MTs NU Sabilul Muttaqin Japan Mejobo Kudus]. Jurnal Manajemen Administrasi Pendidikan, 3(2), 286-301.

Hariyanto, D., Arafat, Y., \& Wardiah, D. (2021). The Effect of Facilities and Motivation on Learning Outcomes of High School Students in Gelumbang, Indonesia. Journal of Social Work and Science Education, 2(1), 95-108. https://doi.org/10.52690/jswse.v2i1.210

Hasbullah. (2012). Otonomi Pendidikan, Kebijakan Otonomi Daerah dan Implikasinya terhadap Penyelenggaraan Pendidikan [Education Autonomy, Regional Autonomy Policies and Its Implications for Education Implementation]. Jakarta: Raja Grafindo Persada.

Merdekawati, D. (2017). Implementasi Manajemen Peningkatan Mutu Berbasis Sekolah (MPMBS) Pada SMA Rintisan Sekolah Bertaraf Internasional (RSBI) [Implementation of School-Based Quality Improvement Management (MPMBS) in International Standard School Pilot Senior High Schools (RSBI)]. Jurnal Manajemen dan Administrasi Pendidikan, 1(1), 1-9.

Moleong, L. (2011). Metodologi Penelitian Kualitatif [Qualitative Research Methodology]. Bandung: Remaja Rosdakarya.

Nuryani, N., Harapan, E., \& Wardiah, D. (2021). Principal's Managerial in Improving the Quality of Education in Primary School. Journal of Social Work and Science Education, 2(1), 52-59. https://doi.org/10.52690/jswse.v2i1.205 
Volume 2 (3) 2021

E-ISSN: 2723-6919 P-ISSN: 2746-0827

Rohma, S., Harapan, E., \& Wardiah, D. (2020). The Influence of School-Based Management and Teacher's Professionalism toward Teacher's Performance. Journal of Social Work and Science Education, 1(1), 13-23. https://doi.org/10.52690/jswse.v1i1.6

Sudaryono. (2009). Metode Penelitian [Research methods]. Jakarta: Rineka Cipta.

Sugiyono. (2015). Metode Penelitian Pendidikan, Pendekatan Kuantitatif, Kualitatif dan $R$ \& $D$ [Educational Research Methods, Quantitative, Qualitative and R\&D Approaches]. Bandung: Alfabeta.

Sunanto. (2015). Implementasi Manajemen Berbasis Sekolah dalam Meningkatkan Mutu Pendidikan Pada SMP Negeri 19 Percontohan Banda Aceh [Implementation of SchoolBased Management in Improving the Quality of Education at the 19 Pilot Junior High School in Banda Aceh]. Jurnal Manajemen dan Administrasi Pendidikan, 3(2), 321-336.

Supriadi, D. (2014). Membangun Bangsa Melalui Pendidikan [Building the Nation Through Education]. Bandung: Remaja Rosdakarya.

Syahru. (2017). Penerapan Manajemen Berbasis Sekolah dalam Pemberdayaan Potensi Guru di SMA Negeri 4 Bulu Kumba [Implementation of School-Based Management in Empowering Teacher Potential at SMA Negeri 4 Bulu Kumba]. Jurnal Manajemen dan Administrasi Pendidikan, 2(2), 152-167.

Widiyastuti, I. (2016). Implementasi Kebijakan Peningkatan Mutu Pendidikan di SMP Muhammadiyah 1 Depok Sleman Yogyakarta [Implementation of Education Quality Improvement Policies at SMP Muhammadiyah 1 Depok Sleman Yogyakarta]. Jurnal Manajemen dan Administrasi Pendidikan, 2(2), 147-162.

Zaini, A. (2015). Manajemen Berbasis Sekolah: Alternatif Peningkatan Mutu Pendidikan Madrasah [School-Based Management: Alternatives for Improving the Quality of Madrasah Education]. Jurnal eL-Tarbawi, 8(1), 69-92. 